\title{
RAZPRAVE
}

\section{VREDNOTENJE NEKDANJE IN SEDANJE PROIZVODNJE NEVARNIH ODPADKOV V LJUBLJANI Z VIDIKA OBREMENJEVANJA PODTALNICE}

\author{
AVTORJA \\ dr. Aleš Smrekar \\ Znanstvenoraziskovalni center Slovenske akademije znanosti in umetnosti, Geografski inštitut Antona Melika, \\ Gosposka ulica 13, SI - 1000 Ljubljana, Slovenija \\ ales.smrekar@zrc-sazu.si
}

\section{dr. Mateja Breg Valjavec}

Znanstvenoraziskovalni center Slovenske akademije znanosti in umetnosti, Geografski inštitut Antona Melika, Gosposka ulica 13, SI - 1000 Ljubljana, Slovenija

mateja.breg@zrc-sazu.si

DOI: $10.3986 / G V 86201$

UDK: 911.375.4:628.19(497.4Ljubljana)

COBISS: 1.02

\section{IZVLEČEK}

Vrednotenje nekdanje in sedanje proizvodnje nevarnih odpadkov $v$ Ljubljani z vidika obremenjevanja podtalnice

Na osrednjem območju Ljubljane, ki je danes skoraj v celoti vodovarstveno območje pitnih virov, je v osemdesetih letih prejšnjega stoletja delovalo vsaj 170 obratov, ki so proizvajali ali skladiščili okolju nevarne snovi. To so bili predvsem obrati strojne in kovinske dejavnosti (predelava kovin, galvane, lakirnice, izdelava strojev, servisi strojne opreme in vozil), živilske (pivovarne, mlekarne), kemične (proizvodnja zdravil, barv, obrati za kemično čiščenje, proizvodnja in skladiščenje kemikalij) ter ostalih dejavnosti (tekstilna industrija, skladiščenje naftnih derivatov). V raziskavi smo podrobneje raziskali današnjo rabo prostora na znanih območjih nevarnih dejavnosti iz osemdesetih let prejšnjega stoletja. Določili smo 309 poslovnih enot, katerih sedež je prav na območju (zemljiških parcelah) nekdanjih obratov in so glede na primarno dejavnost potencialni onesnaževalci podtalnice kot vira pitne vode. Ugotavljamo, da so na $76 \%$ območij (130 od 170) še vedno prisotne dejavnosti, ki proizvajajo, skladiččijo ali prodajajo nevarne snovi. Prevladujejo večja območja, medtem ko so se manjša pogosteje preobrazila. Njihovo stopnjo okoljskega tveganja smo določili predvsem $z$ vidika podtalnice Ljubljanskega polja, ki je glavni vir pitne vode $v$ prestolnici. $Z$ nadaljnjimi terenskimi analizami tal bo treba preveriti ali so območja dejansko onesnažena in jih lahko označimo kot kontaminirana območja.

\section{KLJUČNE BESEDE}

geografija, industrija, nevarni odpadki, potencialno kontaminirano območje, tveganje za onesnaženje, podtalnica, Ljubljana 


\section{ABSTRACT \\ Evaluating former and current production of hazardous waste in Ljubljana from the perspective of threats to groundwater}

In the central part of Ljubljana, which today is almost entirely a water-protection area for drinking water, there were at least 170 facilities operating in the 1980s that produced or stored environmentally hazardous substances. These were primarily facilities in the mechanical and metal industries (metal processing, galvanizing, paint shops, machine production, servicing machinery and vehicles), the food industry (brewing, dairy), the chemical industry (producing medicines, paints, dry cleaning, producing and storing chemicals), and other industries (textiles, storing petroleum derivatives). The study investigates in detail today's use of space at known locations of hazardous industries from the 1980s. We defined 309 business units headquartered at sites (land lots) of former companies (170) whose primary activity created the potential for polluting groundwater as a drinking water source. We determined that at $76 \%$ of the sites (130 of 170) activities are still present that produce, store, or sell hazardous substances. These are primarily large sites, whereas small sites have often been transformed. Their level of environmental risk was primarily defined with regard to the groundwater of the Ljubljana Basin, which is the capital's main source of drinking water. It will be necessary to use further field analysis to check whether the sites are actually polluted and whether they can be defined as contaminated sites.

\section{KEY WORDS}

geography, industry, dangerous waste, potential contaminated site, groundwater, risk for polluting, Ljubljana

Uredništvo je prispevek prejelo 7. aprila 2014. 


\section{Uvod}

V obdobju industrijske revolucije so številna mesta postala industrijska središča. Terciarizacija dejavnosti, globalizacija in informacijska revolucija pa so bili glavni procesi druge polovice 20 . stoletja, $\mathrm{ki}$ so spremenili podobo sodobnih mest. Bole (2008) navaja, da je v slovenskih mestih prišlo do pomembnih funkcijskih sprememb, ki pa so v prvi vrsti posledica družbenoekonomskih sprememb v devetdesetih letih prejšnjega stoletja in se odražajo tudi v njihovi spremenjeni geografski podobi. Najbolj postindustrijski značaj v Sloveniji ima Ljubljana, kjer sočasno potekata dekoncentracija ekonomskih aktivnosti (zlasti industrije) in osredotočanje določenih ekonomskih aktivnosti v središču mesta (terciarne in kvartarne dejavnosti). V Sloveniji je bil proces deindustrializacije posebej izrazit po osamosvojitvi, ko je večina tehnološko zastarelih in nekonkurenčnih industrijskih panog zašla v krizo, kar se je na ravni mesta odrazilo v opuščanju proizvodne rabe. Slednje vodi v degradacijo mestnih območij, v funkcijsko preobrazbo opuščenih proizvodnih območij v bivalna ali trgovska območja, ali v postfordistično proizvodnjo (Bole 2008). Tudi socialnogeografska zgradba mesta doživlja intenzivno preobrazbo, predvsem v smeri povečevanja prostorske socialne segregacije (Rebernik 2013). Šulinova (2007), ki je podrobneje preučevala preobrazbo ljubljanskih industrijskih območij, ugotavlja, da so podobno kot drugod po Evropi, tudi v Ljubljani najopaznejše spremembe doživela industrijska območja, ki so se preobrazila v: trgovsko-poslovna središča, stanovanjske soseske, ali posamezen stanovanjski objekt. Nekaj območij se je preobrazilo v poslovne cone, spet druga pa so ostala industrijska, a z novimi podjetji in panožnimi spremembami industrije.

V praksi je zgodovina ljubljanske industrije vključevala tudi propadanje obratov in opuščanje proizvodnje. Po letu 1991 so se s problemom izgube jugoslovanskega trga soočila vsa večja podjetja. Nekatera so uspešno prestala proces prestrukturiranja in na njihovem območju se je proizvodnja posodobila ali povsem spremenila. Mnoga so propadla in za njimi so ostala degradirana urbana območja (v nadaljevanju DUO), zlasti industrijska. Koželj (1998) navaja, da je bilo konec devetdesetih let prejšnjega stoletja v Ljubljani 168 ha industrijskih DUO, kar predstavlja 32,5\% celotne površine DUO (517,68 ha) v Slovenji. Šulinova (2007) je ugotavljala njihov način preobrazbe, ki je povzet v preglednici 1.

Edina sistematična inventarizacija prostorsko degradiranih območij, ki je bila narejena na ravni Slovenije (Špes s sodelavci 2012), je omejila 11 degradiranih območij (v nadaljevanju DO) znotraj strnjene urbane pozidave v Ljubljani. Iz registra na spletnem portalu Geopedija smo razbrali sledeča DO: Litostroj, industrijsko območje ob Kamniški cesti, Železniški muzej Slovenskih železnic, industrijsko območje ob Kurilniški ulici, IMP, Kolinska, Zelena jama, Javna skladišča BTC, industrijsko območje ob Kajuhovi ulici in Rog.

Omenjene raziskave (Koželj 1998; Šulin 2007; Špes s sodelavci 2012) so DUO oziroma DO preučevale samo $\mathrm{z}$ vidika današnje rabe prostora, ne pa tudi ali je območje kontaminirano zaradi preteklega onesnaževanja ter ali ima to negativen vpliv na podtalnico. Monitoringi podzemne vode na Ljubljanskem polju (izvajajo ga Agencija Republike Slovenije za okolje, Geološki zavod Slovenije, Mestna občina Ljubljana) kažejo, da so v podtalnici prisotna onesnaževala, ki izvirajo iz nekdanje ali sodobne industrijske proizvodnje $\left(\mathrm{Cr}^{6+}\right.$, tetrakloroetilen, trikloroetilen), kar nas spodbuja k nadaljnjim raziskavam in iskanju virov onesnaženja. Znano je, da je bila v preteklosti praksa, da so nevarne odpadne snovi pred nadaljnjo obdelavo in dokončnim odlaganjem (najpogosteje poleg ostalih odpadkov) skladiščili na zemljiščih ob proizvodnih obratih (Allagier in Stegmann 2005).

Skladno s potrebo po poznavanju okoljskega stanja na nekdanjih območjih nevarne industrijske proizvodnje, smo se v raziskavi odločili za celosten zgodovinsko-geografski pristop. Na podlagi študija sekundarnih virov - preteklih študij nevarne industrije (Grilc in Husić 1984; Rihtar in Berkopec 1989), študij degradiranih območij (Koželj 1998; Šulin 2007; Špes s sodelavci 2012), primarnih virov - arhivskih letalskih posnetkov in današnjih prostorskih baz (Poslovni ... 2009), smo v nekdanji in sedanji pokrajini določili območja nekdanjih proizvajalcev nevarnih odpadkov v zemljiškem katastru (parcele) ter ugotavljali kontinuiteto industrije nevarnih odpadkov na teh območjih, nevarnost današnje dejavnosti glede na prevladujočo preobrazbo ter okoljsko tveganje, ki ga imajo za podtalnico. 
Največ industrijskih območij v Ljubljani je prav na Ljubljanskem polju, kjer so vodonosne prodno-peščene in konglomeratne plasti. Gre za enega največjih rezervoarjev podzemne vode v Sloveniji, ki predstavlja naravni vir regionalnega pomena (Bračič Železnik, Pintar in Urbanc 2005). Varstveni pasovi virov pitne vode oziroma vodovarstvena območja, kot jih imenujemo v zadnjem času, imajo na Ljubljanskem polju že dolgo tradicijo. Prvič so jih določili leta 1955. Bili so odločilni za varovanje vodnega vira, ker so omejili širitev mesta in s tem tudi industrijskih obratov v neposredno bližino črpališč (Breznik 1988). V letih 1977 in 1988 sta sledila posodobljena odloka. Ljubljana oskrbuje prebivalstvo in podjetja iz več vodnih virov. Najizdatnejša črpališča pitne vode so prav na Ljubljanskem polju; tamkajšnje vodarne so vključene v centralni vodovodni sistem.

Preglednica 1: Industrijska degradirana urbana območja (Koželj 1998) in njihovo stanje leta 2007 (Šulin 2007) in prevladujoči način preobrazbe.

\begin{tabular}{|c|c|c|}
\hline način preobrazbe & $\begin{array}{l}\text { industrijsko degradirano urbano } \\
\text { območje (Koželj 1998) }\end{array}$ & $\begin{array}{l}\text { sanacija in stanje leta } 2007 \\
(\check{S} \text { ulin 2007) }\end{array}$ \\
\hline \multirow{13}{*}{$\begin{array}{l}\text { ohranjena stara } \\
\text { ali uveljavljena } \\
\text { nova panoga } \\
\text { industrijske } \\
\text { proizvodnje } \\
\text { ali rabe (del } \\
\text { območij še } \\
\text { degradiran) }\end{array}$} & Plutal & obnovljena industrijska cona \\
\hline & Smodinovec & asfaltna baza \\
\hline & Litostroj & industrija se je ohranila deloma prihaja \\
\hline & & do mešanja s terciarnimi dejavnostmi \\
\hline & & (del območja še degradiran) \\
\hline & Pivovarna Union, Slovenijavino & pivovarna Union je ohranjeno industrijsko \\
\hline & & $\begin{array}{l}\text { območje, medtem ko Slovenijavino deluje } \\
\text { v zmanjšanem obsegu }\end{array}$ \\
\hline & Kamniška proga & $\begin{array}{l}\text { industrijska proizvodnja delno ohranjena } \\
\text { (del območja še degradiran) }\end{array}$ \\
\hline & Kolinska & ohranjena industrija, območje sanirano \\
\hline & Zelena jama & $\begin{array}{l}\text { uveljavile so se nove industrijske panoge } \\
\text { (del območia še degradiran) }\end{array}$ \\
\hline & Letališka & nove industrijske panoge \\
\hline & Kašelj & Petrol \\
\hline & Metalka Šentvid & ostaja industrija \\
\hline \multirow{4}{*}{$\begin{array}{l}\text { preobraženo } \\
\text { v poslovno } \\
\text { storitveno cono - } \\
\text { terciarne dejavnosti } \\
\text { (del območij } \\
\text { še degradiran) }\end{array}$} & Pod hribom & poslovna cona \\
\hline & Križišče Celovške in Pečnikove v Dravljah & $\begin{array}{l}\text { preobraženo območje: trgovsko poslovne } \\
\text { dejavnosti }\end{array}$ \\
\hline & Javna skladišča & $\begin{array}{l}\text { trgovsko poslovni kompleks BTC City, } \\
\text { deloma ostaja degradirano }\end{array}$ \\
\hline & Gorenjska proga & $\begin{array}{l}\text { deloma poslovna cona, deloma degradirano: } \\
\text { Unitas, Tehnounion, Avtomontaža }\end{array}$ \\
\hline preobraženo $\mathrm{v}$ & Brdo & tehnološki park v izgradnji \\
\hline $\begin{array}{l}\text { izobraževalno } \\
\text { raziskovalne } \\
\text { dejavnosti - } \\
\text { kvartarne } \\
\text { dejavnosti }\end{array}$ & Ižanska cesta (Hoja) & $\begin{array}{l}\text { biotehniški izobraževalni center, poslovne } \\
\text { dejavnosti, šolska dejavnost v izgradnji }\end{array}$ \\
\hline stanovanjska raba & Agrostroj & stanovanjska soseska Mostec \\
\hline
\end{tabular}


Na podlagi tujih raziskav (Allagier in Stegmann 2005; Elliott in Frickel 2011) in lastnega poznavanja problematike ravnanja z odpadki (Breg in Urbanc 2005; Smrekar 2007; Breg Valjavec 2013), menimo, da so nekdanji proizvajalci nevarnih odpadkov, zaradi nepravilnega ravnanja in odlaganja odpadkov, pustili sledi nevarnih snovi na proizvodnih lokacijah, kar je vplivalo tudi na način preobrazbe oziroma na kontinuiteto dejavnosti na teh območjih. Trdimo tudi, da večje kot je območje, težje se preobrazi v drugo rabo, oziroma manjše je območje, pogosteje spreminja svojo namembnost (Elliott in Frickel 2011).

Območja, na katerih je »tradicionalno« prisotna proizvodnja okolju nevarnih snovi, imajo potencialno večji negativni vpliv na onesnaženje okolja, kakor manjša območja. Cilj raziskave je bil določiti območja tveganja, ki so potencialno onesnažena zaradi pretekle proizvodnje nevarnih snovi in imajo zaradi tega omejitve, ki jih je treba upoštevati pri načrtovanju prihodnje rabe prostora.

\section{Metodologija}

Pridobivanje podatkov o starih, a danes nedelujočih onesnaževalcih je temeljilo na posodobitvi in georeferenciranju podatkov starejših okoljskih študij (Grilc in Husić 1984; Rihtar in Berkopec 1989) ter dopolnilnih virov (Čižman 2006; Medmrežje 1-6). Iz teh smo povzeli podatke o lokaciji, ki je bila podana bodisi z naslovom (ulica in hišna številka) bodisi z Gauss-Krügerjevimi koordinatami. Natisnjene preglednice smo digitalizirali in predelali v georefrencirano podatkovno tabelo. Objekte nekaterih onesnaževalcev smo zajemali iz arhivskega kartografskega gradiva. Poleg zelo natančne študije o proizvajalcih nevarnih odpadkov iz leta 1984 (Grilc in Husić), ki vključuje podatke o vrsti in letni količini nastalih nevarnih odpadkov, smo iz nekaterih vzporednih študij iz osemdesetih let prejšnjega stoletja (Rihtar in Berkopec 1989) pridobili podatke še o dodatnih lokacijah proizvajalcev nevarnih odpadkov. »Kataster posebnih odpadkov v Ljubljanski regiji« (Grilc in Husić 1984) predstavlja seznam industrijskih objektov, ki so proizvajali nevarne snovi. Narejen je bil na podlagi natančnega pregleda podatkov o odpadnih materialih v različnih industrijskih dejavnostih. Podatki so bili zbrani na podlagi izpolnjenih popisnih obrazcev s strani delovnih organizacij. Pričujoči popis temelji na podatkih o količinah in sestavi odpadkov v letu 1982. Elaborat "Stanje na varstvenih pasovih virov pitne vode na območju Ljubljane iz katerih se oskrbuje nad 10.000 prebivalcev« (Rihtar in Berkopec 1989) podaja seznam nekdanjih industrijskih objektov (stanje 1988), ki so proizvajali nevarne snovi in so bili potencialni onesnaževalci. Nastal je na temelju podatkov, ki jih je zbral Mestni štab za civilno zaščito (Klasifikacija OZD in drugih DO, ki uporabljajo ali imajo nevarne snovi), podatkov Elektrogospodarstva Ljubljana-mesto, Zavoda SRS za statistiko in Zveze vodnih skupnosti Slovenije. Klasifikacija nevarnih snovi temelji na oceni stopnje škodljivosti za zdravje ljudi in drugo živo naravo, požarne nevarnosti in eksplozivnosti. Rezultat so točkovno opredeljene lokacije nekdanjih objektov (slika 1).

Zaradi uporabe starih podatkov, katerih lokacije so bile zajete na zemljevidih manjšega merila, je lahko ponekod že izhodiščna lega napačno označena, zato v takšnih primerih analiza ne more podati povsem ustreznega rezultata.

Nadgradnja točkovne opredelitve lokacije (centroid) je razširitev na območje, ki ga je pokrival nekdanji proizvodni obrat. Točkovne podatke smo navezali na obstoječi zemljiški kataster (digitalni katastrski načrt - DKN); natančneje na parcele. Parcela, na kateri leži centroid, je skoraj zagotovo pripadala proizvodnemu obratu, medtem ko smo okoliške parcele poskusili definirati s pomočjo vizualne interpretacije arhivskih letalskih posnetkov. Uporabili smo kombinacijo posnetkov cikličnega aerofotosnemanja (CAS) iz 1975 in 1985. Rezultat so zemljiško (poligonsko) opredeljena stara industrijska območja, usklajena z DKN (slika 2).

Današnjo gospodarsko namembnost zemljišč smo določili iz Poslovnega registra Slovenije (2009) in iz podatkovne baze zavezancev industrijskih izpustov v kanalizacijo (Iztoki ... 2009). Določili smo le tiste aktualne dejavnosti, kjer so še vedno posredno ali neposredno prisotni procesi, povezani z nastankom nevarnih snovi, predvsem z vidika ogrožanja podtalnice. Poslovne objekte, ki so potencialno nevarni 
za onesnaženje podtalnice in okolja, smo razvrstili na podlagi aktualnih onesnaževal v podtalnici in druge nevarne snovi: $\mathrm{Cr}^{6+}$, tetrakloroetilen, trikloroetilen in druge kemikalije. Gre za obrate s primarno dejavnostjo po standardni klasifikaciji dejavnosti, ki so porabniki vode, katerih odpadne vode so lahko potencialno onesnažene $\mathrm{z}$ navedenimi kemikalijami: prekrivanje kovin s kovino (galvanizacija), dejavnost pralnic in kemičnih čistilnic, litje jekla, proizvodnja kovin, konstrukcij in njihovih delov, proizvodnja elektronskih komponent, vzdrževanje in popravila motornih vozil, proizvodnja piva, ravnanje z nevarnimi odpadki, zobozdravstvene in zdravstvene dejavnosti ter drugo. Podatki so prostorsko vezani na sedež podjetja, zato so v nekaterih primerih, kjer je proizvodnja na drugi lokaciji, podatki nepredmetni.

\section{Rezultati in razprava}

Za preteklo socialistično obdobje je bilo značilno neučinkovito izvajanje okoljskih zakonov in industrokracija (Breznik 1990). Slednje pomeni, da je imela industrija v Sloveniji tako močan vpliv na politiko in upravo, da je lahko dolga leta brez kaznovanja onesnaževala okolje. Za ljubljansko industrijo v sedemdesetih in osemdesetih letih preteklega stoletja so bile značilne:

- velika heterogenost (zastopane so bile skoraj vse panoge industrije),

- razdrobljenost zmogljivosti,

- dejanska in tehnološka zastarelost osnovnih sredstev,

- premajhna avtomatizacija tehnoloških postopkov ter

- dokajšnja usmerjenost na uvozne surovine.

Koncept razvoja je temeljil na štirih prednostnih panogah oziroma nosilcih razvoja: kmetijsko živilski industriji (Žito Ljubljana, Ljubljanske mlekarne, Emona Ljubljana), strojegradnji/kovinski (Litostroj, Indos, Agrostroj, IMP, galvane), elektroindustriji (Iskra s TOZD-i, Tego s TOZD-i) ter kemični in farmacevtski industriji (SOZD Polikem, SOZD Belinka, Teol, Ilirija, Vedrog, Julon, Lek) (Cerkvenik 1977 v: Šulin 2007). Ljubljanska industrijska proizvodnja je svoj višek doživela v osemdesetih letih prejšnjega stoletja, o čemer pričajo podatki o številu delavcev, zaposlenih v industriji in številu registriranih podjetij. Po ustvarjeni vrednosti družbenega proizvoda industrije v Ljubljani je bila na prvem mestu kovinska industrija (21,9\%), na drugem mestu živilska (17,6\%), kemična industrija z nekaterimi novimi obrati (Lek, Bayer Pharma, Belinka) pa je bila tretja najmočnejša panoga (14,1 \%). Popolnoma nova panoga, ki se je razvila šele po drugi svetovni vojni, je bila elektroindustrija in je bila po družbenem proizvodu na devetem mestu (10,5\%). Nekoliko močnejše panoge so bile še: grafična, papirna in tekstilna industrija (Cerkvenik 1977 v: Šulin 2007). Stopnja nevarnosti tedanje industrije z vidika ogrožanja podtalnice je bila opredeljena s sledečimi kategorijami (Rihtar in Berkopec 1989; slika 1):

I - Delovne organizacije, ki imajo, uporabljajo ali prevažajo nevarne snovi v količinah, ki predstavljajo zelo veliko nevarnost za okolico (na primer lahko vnetljive tekočine, jedke in agresivne snovi ter strupene snovi, ki pomenijo pri razlitju oziroma razsutju veliko nevarnost za okolico).

II - Delovne organizacije, ki imajo oziroma uporabljajo nevarne snovi v svojih delovnih procesih v količinah, potrebnih za normalen potek dela. Organizacije, ki imajo oziroma uporabljajo nevarne snovi pri svojih delovnih procesih ob upoštevanju ukrepov varovanja. Količine so prilagojene potrebam za normalen potek dela. Organizacije so v gosto naseljenih območjih. Do njih je treba nevarne snovi pripeljati po cesti.

III - Črpalke oziroma skladišča za naftne derivate.

IV - Objekti, kjer so naprave napolnjene z olji, ki vsebujejo PCB.

Kataster posebnih odpadkov (Grilc in Husić 1984) predstavlja celovito študijo o proizvajalcih nevarnih snovi v tedanjih industrijskih obratih na območju Ljubljane (podatki študije so prikazani na sliki 1, pod legendo »količina odpadkov (1982)«, dejavnost pa z rumenim besedilom na zemljevidu). Študijo, ki je ob nastanku ostala na ravni analognega katastra, smo spremenili v digitalni register in ga vključili 
v GIS okolje. Analogne podatke smo spremenili v digitalno obliko (kataster je vseboval podatek o lokaciji) in izdelali informacijski sloj z vsemi obstoječimi podatki, kjer smo največ pozornosti namenili količini odpadkov, vrsti nevarnih odpadkov in načinu ravnanja $\mathrm{z}$ odpadki. Podatke smo priredili na območje vodonosnika Ljubljansko polje in analizirali 35 podjetij v okviru katerih deluje 65 proizvodnih obratov.

Kot primer kovinske industrije navajamo Tovarno kovinske galanterije, ki je imela v osemdesetih letih prejšnjega stoletja štiri proizvodne obrate, kjer so uporabljali različne proizvodne procese in proizvajali različne tipe industrijskih odpadkov. To so bili: galvana, lakirnica, obrat za toplotno obdelavo kovin in obrat montaže. V galvani je letno nastajalo okrog 45 ton zelo strupenih trdnih odpadkov (kovinski hidroksidi $\left(\mathrm{Cu}^{2+}, \mathrm{Ni}^{2+}, \mathrm{Cr}^{3+}, \mathrm{Cr}^{6+}\right)$, cianidi, fosfati, nitriti), ki so jih po predhodnem postopku shranjevali $\mathrm{v}$ dvesto litrskih sodih in odlagali na odlagališče komunalnih odpadnih snovi (ni znano ali legalno ali nelegalno). Obrat za toplotno obdelavo kovin je leta 1982 proizvedel 2,25 tone nekoliko manj nevarnih odpadkov kalilnega repičnega olja, ki so ga po predhodnem postopku odložili na odlagališče komunalnih odpadnih snovi. Lakirnica je proizvedla 0,3 tone zelo nevarnih odpadnih snovi (smole, svinčevi kromati, Zn-kromat, Ti02, butanol, ksilen) v trdnem stanju, ki so jih prav tako po predhodnem postopku odložili na odlagališče komunalnih odpadnih snovi. V preostalih obratih so proizvedli še okrog tono in pol motornih olj ter tovornih masti v obliki gošče skladiščene v dvesto litrskih kovinskih sodih.

V neposredni bližini vodarne Kleče, najstarejšega (iz leta 1890) in največjega črpališča pitne vode v Ljubljani, je le $700 \mathrm{~m}$ proti severovzhodu v III. varstvenem pasu virov pitne vode delovala tovarna Unis-TOS, tovarna opreme $\mathrm{z}$ lakirnico in toplotno obdelavo kovin. Letno so proizvedli okrog pet ton zelo nevarnih snovi (smole, svinčevi kromati, Ti02, Zn-kromat, butanol, ksilen, cianidi, nitrati, nitriti), ki so se odlagale na usedalniku; v dvesto litrskih sodih pa so skladiščili trden preostanek (štiri tone letno) manj nevarnih snovi po destilaciji trikloretilena. Severozahodno od črpališča v Klečah so bili zgoščeni obrati Iskre (Iskra Industrija baterij Zmaj Ljubljana), IMP Ljubljana DO - IKO Ljubljana TOZD Trata Ljubljana in Dekorativa TOZD Surova tkanina Ljubljana. V Iskri podatkov o količini nastalih nevarnih odpadkov nismo pridobili, medtem ko so bili zbrani podatki za skladiščenje nevarnih snovi (kalijev hidroksid, kromat, amalgam, živosrebrov (II) oksid, magnezijev dioksid, kalilno olje (repično olje)) v sodih, ki so bili odloženi na neznano mesto.

Na levem bregu Save v dotočni smeri vodarne Jarški prod je prav tako v III. varstvenem pasu virov pitne vode v osemdesetih letih prejšnjega stoletja obratovalo pet podjetij, ki so proizvajala nevarne odpadne snovi: Elma Črnuče (galvana), Inkop Kočevje (lakirnica), Energoinvest Sarajevo, Tovarna transformatorjev Ljubljana - Črnuče (lakirnica), MP TOZD Dvigalo Ljubljana - Črnuče (obrat lakirnice ter obrat hladilne in rezalne emulzije). Skupaj so proizvedla 25 ton zelo nevarnih snovi v trdnem stanju (smole, svinčevi kromati, Zn-kromat, $\mathrm{TiO}_{2}$, butanol, ksilen, $\mathrm{Zn}^{2+}, \mathrm{Fe}^{3+}, \mathrm{Ni}^{2+}, \mathrm{Cu}^{2+}, \mathrm{Cr}^{6+}, \mathrm{Cr}^{3+}$ ), ki so se delno odlagale na komunalna odlagališča, za del odpadkov pa ni podatka o ravnanju ali kraju odlaganja. Na območju Ljubljane je konec osemdesetih let prejšnjega stoletja delovalo skupno tudi 24 obratov za površinsko obdelavo kovin (galvanizacija, toplotna obdelava). Z natančno geolokacijo teh obratov smo določili njihove lege glede na obstoječa vodovarstvena območja.

Določili smo 309 poslovnih subjektov (Poslovni ... 2009), katerih sedež je na območju (zemljiških parcelah) nekdanjih obratov in imajo glede na primarno dejavnost, potencialno možnost za onesnaženje podtalnice (slika 2). Ugotavljamo, da so na $76 \%$ območij (130) še vedno prisotne dejavnosti, ki proizvajajo, skladiščijo ali prodajajo nevarne snovi. Njihovo stopnjo okoljskega tveganja smo določili predvsem $\mathrm{z}$ vidika podtalnice Ljubljanskega polja, ki je glavni vir pitne vode v prestolnici (Medmrežje 7).

Slika 1: Nekdanji proizvajalci nevarnih odpadkov (stanje 1988) in količina nastalih odpadkov (stanje 1982) ter stanje gramoznic (INCOME 2012), kot potencialnih mest za odlaganje industrijskih odpadkov na Ljubljanskem polju. $>$ str. 18

Slika 2: Območja kontinuirane in spremenjene proizvodnje nevarnih snovi in njihovo tveganje za onesnaženje podtalnice. $>$ str. 19 


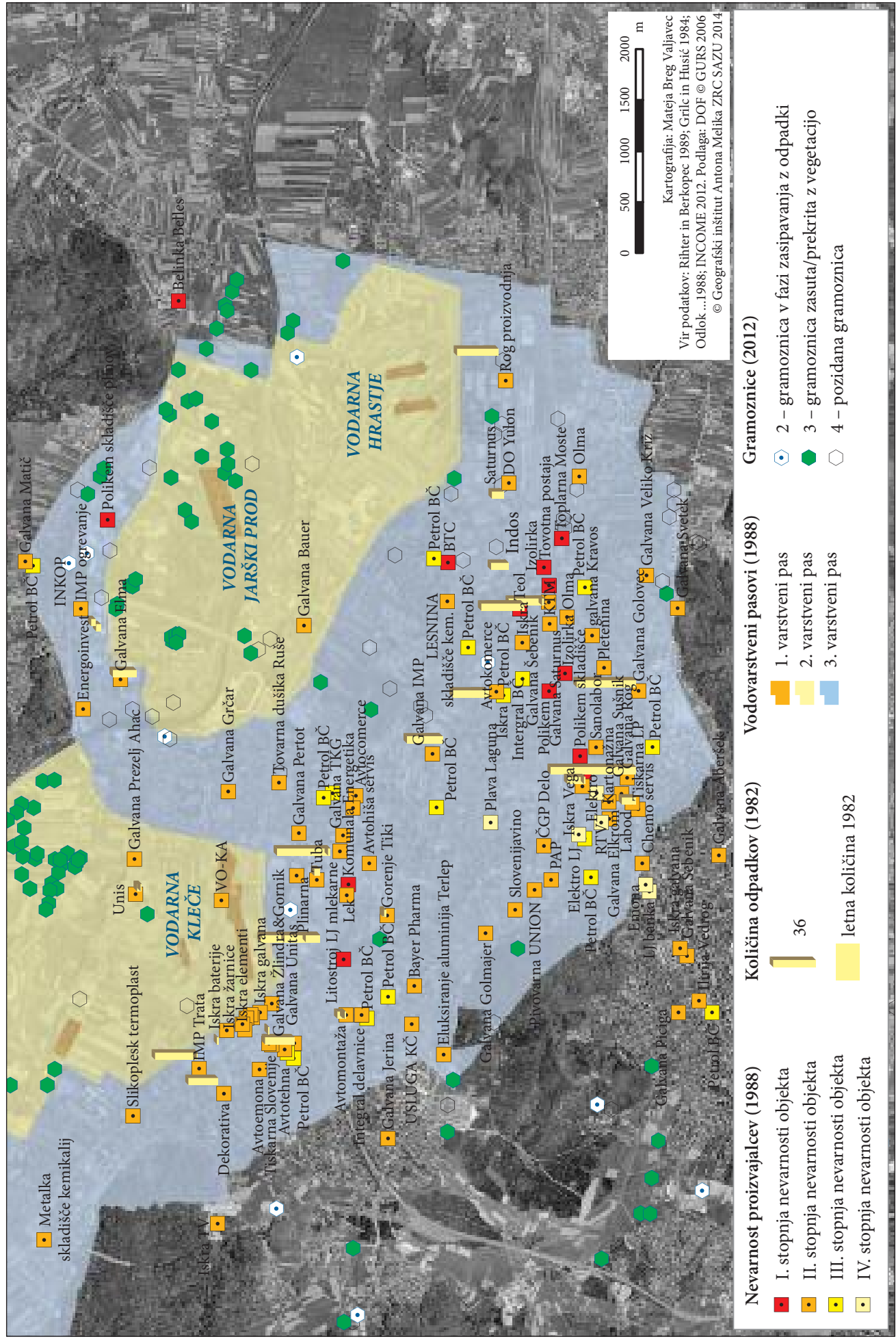




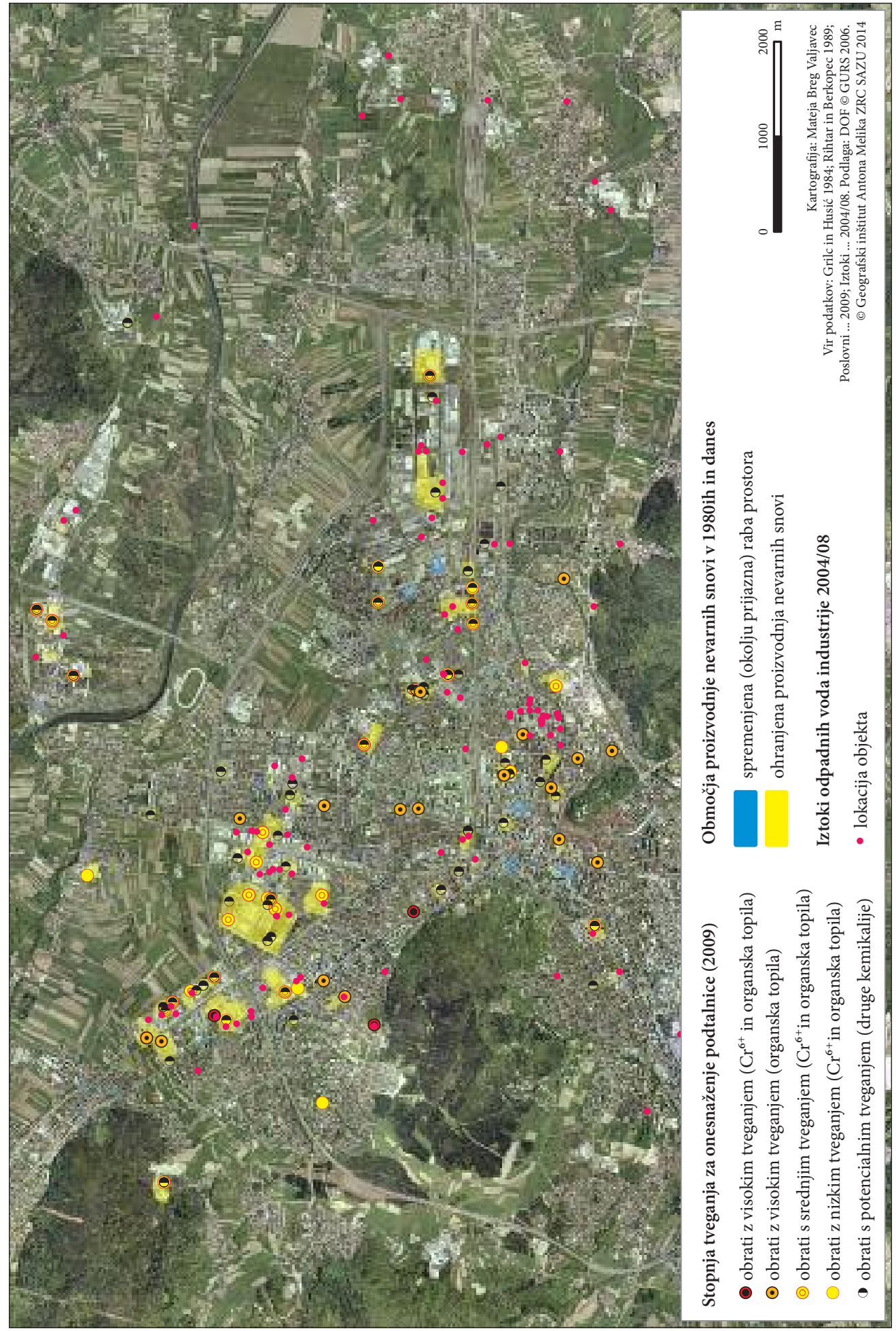


Del proizvodnje nekdanjih velikih podjetij (izbrali smo podjetja, ki so proizvajala nevarne odpadke) je v bolj ali manj spremenjeni lastniški (proces lastninjenja) in organizacijski obliki (TOZD-i so se preoblikovali v samostojna podjetja) ostal na isti lokaciji od leta 1982 oziroma 1989 do 2009. Parcele, ki so bile v lasti nekdanjega, ponekod sovpadajo z novim podjetjem. Kot primer navajamo razpad industrijskega velikana Litostroj leta 1991. Celoten kompleks je prestal tranzicijsko obdobje in se organizacijsko preoblikoval v nova podjetja, z novimi lastniki (na primer Litostroj Power je naslednik TOZD-a Energetika in je bil do leta 2014 v lasti koprskega podjetja Cimos, ki ga je prodal tujcem). Običajno so skupaj z objekti lastnike zamenjala tudi zemljišča, kar je tudi razvidno v zemljiškem katastru in zemljiški knjigi. Območje je še vedno namenjeno industrijski proizvodnji, ki v svoje procese vključuje snovi, ki so nevarne podtalnici.

Proizvodna podjetja, ki smo jih preučevali, so v dolgih letih proizvajala odpadke v trdem, tekočem ali plinastem stanju in onesnaževala okolje. Onesnaževala industrijskega izvora so fenolne snovi, mineralna olja, poliklorirani bifenili (PCB), organska klorirana topila, fosforne in kositrove spojine, živo srebro in drugi. Med manj nevarnimi onesnaževalci fekalnega in kmetijskega izvora so nitriti, amonijak in nitrati, med nevarnimi pa herbicidi, predvsem atrazin. Poliklorirani bifenili so se nahajali v barvah, ki sta jih uporabljali lesna in tekstilna industrija.

Problematika odlaganja nevarnih odpadkov, ki so nastajali v industrijskih obratih v obdobju od petdesetih do konca osemdesetih let prejšnjega stoletja in so jih odlagali na neznanih lokacijah, ostaja nerešena do danes kljub dejstvu, da je katastrov divjih odlagališč za območje Ljubljane več (Kobal, Spruk in Špendl 1999; Kušar 2000; Berden Zrimec, Ružič in Leskovar 2004; Smrekar 2006; Breg Valjavec, Kladnik in Smrekar 2007). Značilnost odloženih odpadkov iz ljubljanske industrije v obdobju od 1950 do 1970 je poleg organskih tudi velik delež drobnega inertnega materiala, kot so pepel, žlindre, prst in gradbeni odpadki (Orožen Adamič in Pleskovič 1975). Fenolne snovi, organske klorirane fosforne in kositrove spojine ter težke kovine uporablja industrija. Organska klorirana topila so uporabljale vse čistilnice za čiščenje oblačil ter kovinska industrija za razmaščevanje kovin pred barvanjem. Živo srebro je uporabljala mlekarska industrija za dezinfekcijo, mineralna olja pa strojna industrija.

Industrija je zelo obremenjevala območja, na katerih je delovala, kar dokazuje tudi študija o vplivih na okolje za območje industrijske cone Zelena jama (Šulin 2007). Južni del cone je okoljsko obremenjen $z$ vidika onesnaženosti tal, zakopanih odpadkov, emisij v zrak ter stopnje tveganja za zdravje ljudi. Površinska plast je onesnažena s kovinami in mineralnimi olji, ki presegajo mejne in opozorilne vrednosti in so nevarne zaradi potencialnega izpiranja v podtalnico. Celotno območje je lahko obremenjeno z odpadki, in to kljub temu, da leži v III. varstvenem pasu virov pitne vode. Obstaja sum, da so tu v preteklosti zakopavali nevarne odpadke (Šulin 2007). Z nadaljnjimi terenskimi analizami bo treba preveriti ali so območja, označena na sliki 2, le potencialna grožnja podtalnici ali so dejansko tudi onesnažena, in jih lahko označimo kot kontaminirana območja.

\section{Sklep}

Na regionalni ravni, to je na ravni Ljubljanske urbane regije, ugotavlja Bole (2008) določen premik k prerazporeditvi gospodarskih dejavnosti, zlasti v smeri decentralizacije iz mesta na suburbanizirana obmestja. Z rezultati naše raziskave, ki se sicer osredotočajo le na strnjeno urbano pozidavo na varstvenih pasovih virov pitne vode na Ljubljanskem polju, lahko te ugotovitve le deloma potrdimo. Kljub intenzivnemu umikanju trgovskih in storitvenih dejavnosti na obrobje mesta (v obrtno industrijske cone: BTC, Vič, Rudnik), ostaja namreč še velik del ohranjene in novejše (postfordistične) proizvodnje na lokacijah starejših predtranzicijskih podjetij. Glavno industrijsko območje v Ljubljani ostaja območje nekdanje občine Ljubljana Šiška, predvsem industrijski coni med kamniško in gorenjsko železniško progo ter med gorenjsko progo in Celovško cesto (Šulin 2007). Ta območja predstavljajo potencialno tveganje 
za ljubljanske vire pitne vode. Območja imajo ugodno prometno lego in dostopnost ter urejeno komunalno infrastrukturo.

Znotraj strnjenih urbanih zemljišč ostajajo posamezna degradirana urbana območja (Koželj 1998; Špes in sodelavci 2012), ki pa s časom lahko obnovijo svojo prvotno industrijsko vlogo oziroma se njihova raba popolnoma spremeni v terciarno ali kvartarno dejavnost oziroma v rezidenčno območje (tudi parki, parkirišča, igrišča).

$\mathrm{V}$ raziskavi smo podrobneje raziskali današnjo rabo prostora na območjih nevarnih dejavnosti iz osemdesetih let prejšnjega stoletja. Določili smo 309 poslovnih enot (Poslovni ... 2009), katerih sedež je na območju (zemljiških parcelah) nekdanjih obratov in so glede na primarno dejavnost potencialni onesnaževalci podtalnice. Ugotavljamo, da so na $76 \%$ območij (130) še vedno prisotne dejavnosti, ki proizvajajo, skladiščijo ali prodajajo nevarne snovi. Njihovo stopnjo okoljskega tveganja smo določili predvsem z vidika podtalnice Ljubljanskega polja, ki je glavni vir pitne vode v prestolnici (Medmrežje 7).

V kontekstu svetovne literature lahko tudi za Ljubljano potrdimo uveljavljeno tezo, da večje kot je industrijsko območje, težje se preobrazi v drugo panogo oziroma drugo rabo prostora in obratno, manjše kot je območje, pogosteje spreminja svojo namembnost (Elliott in Frickel 2011). Območja, na katerih je »tradicionalno « prisotna proizvodnja okolju nevarnih snovi, imajo potencialno večji negativni vpliv na onesnaženje okolja, kakor manjša območja. Območja tveganja, ki so potencialno onesnažena zaradi pretekle proizvodnje nevarnih snovi, imajo zaradi tega omejitve, ki jih je treba upoštevati pri načrtovanju prihodnje rabe prostora. Še zlasti, če se nahajajo nad viri pitne vode.

Zahvala: Članek je rezultat raziskovalnega projekta INCOME - Skrb za učinkovito upravljanje onesnaženih vodonosnikov (LIFE07 ENV/SLO/000725). Za sofinanciranje se zahvaljujemo Evropski komisiji, takratnemu Ministrstvu za okolje in prostor ter Mestni občini Ljubljana.

\section{Viri in literatura}

Allgaier, G., Stegmann, R. 2005: Old landfills in the contex of regional planning - Developing of a simplified preliminary risk assessment method. Cabernet 2005: The International Conference on Managing Urban Land. Belfast.

Ciklično aerofoto snemanje (CAS). Geodetska uprava Republike Slovenije. Ljubljana, 1975.

Ciklično aerofoto snemanje (CAS). Geodetska uprava Republike Slovenije. Ljubljana, 1985.

Berden Zrimec, M., Ružič, R., Leskovar, R. 2004: Popis divjih odlagališč odpadkov (črne deponije) na območju Mestne občine Ljubljana. Bion, Inštitut za bioelektromagnetiko in novo biologijo. Ljubljana.

Bole, D. 2008: Ekonomska preobrazba slovenskih mest. Geografija Slovenije 19. Ljubljana.

Breg, M., Urbanc, M. 2005: Prodna ravnina v mestnem prostoru: gramoznice kot prvina degradirane pokrajine. Acta geographica Slovenica 45-2. Ljubljana. DOI: 10.3986/AGS45202

Breg Valjavec, M. 2013: Nekdanja odlagališča odpadkov v vrtačah in gramoznicah. Geografija Slovenije 26. Ljubljana.

Breg Valjavec, M., Kladnik, D., Smrekar, A. 2007: Odlagališča odpadkov na vodovarstvenem območju Ljubljanskega polja, glavnem viru oskrbe Ljubljane s pitno vodo. Acta geographica Slovenica 47-1. Ljubljana. DOI: 10.3986/AGS47104

Bračič Železnik, B., Pintar, M., Urbanc, J. 2005: Naravne razmere vodonosnika. Podtalnica Ljubljanskega polja. Geografija Slovenije 10. Ljubljana.

Breznik, M. 1988: Analiza odlokov o zaščiti ljubljanskih virov pitne vode. Ljubljanski ekološki dnevi 88. Ljubljana.

Breznik, M. 1990: Ogroženost podtalnice. Ujma 4. Ljubljana.

Čižman, M. 2006: Ljubljana: Ulice, ceste in trgi po župnijah. Ljubljana.

DOF - Digitalni ortofoto. Geodetska uprava Republike Slovenije. Ljubljana, 2006. 
Elliott, J. R., Frickel, S. 2011: Environmental dimension of urban change: uncovering relict industrial waste sites and subsequent land use conversions in Portland and New Orleans. Journal of Urban Affairs 33-1. Blacksburg. DOI: 10.1111/j.1467-9906.2010.00533x

Grilc, V., Husić, M. 1984: Kataster posebnih odpadkov v Ljubljanski regiji. Kemijski inštitut »Boris Kidrič«. Ljubljana.

INCOME, Učinkovito upravljanje onesnaženih vodonosnikov - povezava postopkov za odkrivanje in nadzor virov onesnaženja ter ukrepov za izboljšanje stanja. Ljubljana, 2012. Medmrežje: http://www.life-income.si/ (21.9.2014).

Iztoki odpadnih voda industrije v kanalizacijo 2004-08. Agencija Republike Slovenije za okolje. Ljubljana, 2009.

Kobal, J., Spruk, B., Špendl, R. 1999: Popis odlagališč odpadkov v Mestni občini Ljubljana. Oikos d. o. o. Ljubljana.

Koželj, J. 1998: Degradirana urbana območja. Ljubljana.

Kušar, S. 2000: Geografske značilnosti odlagališč odpadkov na Ljubljanskem polju. Diplomsko delo, Oddelek za geografijo Filozofske fakultete Univerze v Ljubljani. Ljubljana.

Medmrežje 1: http://www.rumenestrani.com/ (20.3.2010).

Medmrežje 2: http://zemljevid.najdi.si/ (20.3.2010).

Medmrežje 3: http://www.petrol.si/ (20.3.2010).

Medmrežje 4: http://www.bizi.si/ (20.3.2010).

Medmrežje 5: http://www.pirs.si/ (20.3.2010)

Medmrežje 6: http://www.itis.si/ (20.3.2010).

Medmrežje 7: http://www.life-income.si (junij 2012).

Odlok o varstvu virov pitne vode. Uradni list Socialistične republike Slovenije 13/1988. Ljubljana.

Orožen Adamič, M., Pleskovič, B., 1975: Problemi okolja in odlaganje trdnih odpadkov v Ljubljani. Geografski vestnik 47. Ljubljana.

Poslovni register Slovenije. Agencija Republike Slovenije za javnopravne evidence in storitve. Ljubljana, 2009.

Rebernik, D. 2013: Social areas in Ljubljana. Dela 39. Ljubljana. DOI: 10.4312/dela.39.1.5-26

Geodetska uprava Republike Slovenije (GURS): Register prostorskih enot. Ljubljana, 2009.

Rihtar, H., Berkopec, G. 1989: Stanje na varstvenih pasovih virov pitne vode na območju Ljubljane iz katerih se oskrbuje nad 10.000 prebivalcev. Ljubljana.

Smrekar, A. 2006: Zavest ljudi o pitni vodi. Geografija Slovenije 12. Ljubljana.

Smrekar, A. 2007: Stihijski (ne)razvoj neurbaniziranega dela mesta na primeru Ljubljane. Dela 28. Ljubljana. Špes, M., Krevs, M., Lampič, B., Mrak, I., Ogrin, M., Plut, D., Vintar Mally, K., Vovk Korže, A. 2012: Sonaravna sanacija okoljskih bremen kot trajnostno razvojna priložnost Slovenije, Degradirana območja. Ciljni raziskovalni program (CRP) »Konkurenčnost Slovenije 2006-2013 «zaključno poročilo. Oddelek za geografijo Filozofske fakultete Univerze v Ljubljani, Ljubljana.

Šulin, A. 2007: Preobrazba industrijskih območij v Mestni občini Ljubljana. Diplomsko delo, Filozofska fakulteta Univerze v Ljubljani. Ljubljana.

\section{Summary: Evaluating former and current production of hazardous waste in Ljubljana from the perspective of threats to groundwater (translated by DEKS d. o. o.)}

Many cities became industrial centers during the industrial revolution. Tertiary activities, globalization, and the information revolution were the main processes in the second half of the twentieth century that changed the character of today's cities. Bole (2008) states that in Slovenian towns there were important functional changes that were first of all a consequence of socioeconomic changes in 
the 1990s and are also expressed in their geographical character. The town with the most postindustrial character in Slovenia is Ljubljana, where there is a simultaneous deconcentration of economic activities (especially industry) and a focusing of specific economic activities in the center of the town (tertiary and quaternary activities). In Slovenia, the deindustrialization process was especially noticeable after independence, when the majority of technologically outdated and uncompetitive industries entered a crisis, which was expressed at the town level with the abandonment of production. This led to degradation of urban sites and to the functional transformation of abandoned production sites into residential or commercial sites, or post-Fordist production (Bole 2008). Koželj (1998) states that at the end of the 1990s there were 168 ha of degraded urban sites in Ljubljana, representing $32.5 \%$ of all degraded urban areas in Slovenia (517.68 ha). Sulin (2007) determined their manner of transformation, summarized in Table 1. The environmental problem of Ljubljana industry is especially connected with groundwater pollution. The most industrial areas in Ljubljana are located precisely in the Ljubljana Basin, where water-bearing gravel-sand and conglomerate strata fill the basin. This is one of the largest groundwater reservoirs in Slovenia and is a natural resource of regional significance (Bračič Železnik et al. 2005). Groundwater monitoring in the Ljubljana Basin (by the Environmental Agency of the Republic of Slovenia, Geographical Survey of Slovenia, and City of Ljubljana) indicates that the groundwater contains pollutants that originate in former or current industrial production $\left(\mathrm{Cr}^{6+}\right.$, tetrachloroethylene, trichloroethylene), which provides an incentive for further research and finding sources of pollution. In line with the need to identify the ecological status at sites of former hazardous industrial production, for this study we selected a comprehensive historical-geographical approach. Based on a study of secondary sources: past studies of hazardous industries (Grilc and Husić 1984; Rihtar and Berkopec 1989), studies of degraded areas (Koželj 1998; Šulin 2007; Špes et al. 2012) and primary sources: archival aerial photos and a current spatial database (Poslovni ... 2009), we defined areas of former producers of hazardous waste in the former and current landscape on the land cadaster (lots) and determined the continuity of industries with hazardous waste at these sites, the hazard of today's activities with regard to the main transformation, and the ecological risk that this poses for groundwater.

Ljubljana's industrial production reached its peak in the 1980s, which is also shown by data on the number of workers employed in industry and the number of registered companies. According to GDP of industrial origin in Ljubljana, the metal industry was in first place $(21.9 \%)$, the food industry second (17.6\%), and the chemical industry third (14.1\%). A completely new industry, which developed only after the Second World War, was the electrical industry, which was in ninth place for GDP (10.5\%). Somewhat stronger industries were graphics, paper, and textiles. The hazard level in the industries of that time with regard to threatening groundwater was defined with the following categories (Rihtar and Berkopec 1989; Figure 1):

I. Facilities that have, use, or transport hazardous substances in quantities that represent a very high threat to the environment (e.g., flammable liquids, corrosive and aggressive substances, and poisonous substances, which represent a great threat to the environment in the case of spills or dispersion).

II. Facilities that have or use hazardous substances in their work in quantities required for normal operations. Facilities that have or use hazardous substances in their operations while taking into account protective measures. Quantities are adapted to the needs of normal operation. The facilities are in densely settled areas. Hazardous substances must be transported to them by road.

III. Pumps or storage for petroleum derivatives.

IV. Structures where equipment is filled with oils containing PCBs.

The study investigates in detail today's use of space at known locations of hazardous industries from the 1980s. We defined 309 business units (Poslovni ... 2009) headquartered at sites (lots) of former companies whose primary activity created the potential for groundwater pollution. We determined that at $76 \%$ of the sites (130) activities are still present that produce, store, or sell hazardous substances. We defined their level of ecological risk primarily with regard to the groundwater of the Ljubljana Basin, which is the capital's main source of drinking water (Medmrežje 7). The findings of this study, which 
focuses only on the densely built-up urban area in protection zones for drinking water sources in the Ljubljana Basin, indicate that, despite the large-scale withdrawal of commercial and service activities to business zones on the outskirts of town (BTC, Vič, Rudnik; Bole 2007), there still remains a large amount of preserved and new (post-Fordist) production at the locations of old pre-transition companies. The main industrial area in Ljubljana is still the area of the former Municipality of Ljubljana-Šiška, especially the industrial zone between the Kamnik and Gorenjska (Upper Carniola) railroads, and between the Upper Carniola railroad and Celovška Street (Šulin 2007). These areas have a favorable transport location and accessibility, and good communal infrastructure. Within the dense urban areas and in specific parts of the former industrial areas there nonetheless still remain individual degraded urban sites (Koželj 1998; Šulin 2007; Špes 2012), which are gradually renewing their original industrial role or completely changing their use to tertiary or quaternary activity or to residential areas (and also parks, parking areas, and playgrounds; Table 1). In the context of international literature on the topic, the established thesis can also be asserted for Ljubljana that the greater the industrial area, the more difficult it is to transform it into a different industry or to different use of space and, conversely, the smaller the area, the more often its intended use changes (Elliott and Frickel 2011). Areas in which there is a »traditional» presence of production of environmentally hazardous substances have the potential for greater negative impact on environmental pollution than smaller areas. Risky areas that are potentially contaminated because of past production of hazardous substances therefore have restrictions that must be taken into account when planning future spatial use-especially when they lie above drinking water sources. 